\title{
Water quality key to state's prosperity
}

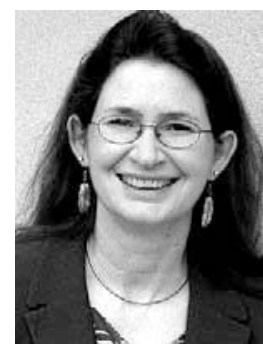

Barbara Allen-Diaz Professor

Rangeland Ecology and Management, UC Berkeley

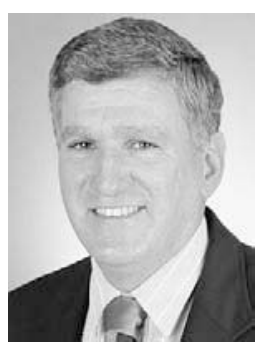

William E. Frost Program Leader Agriculture and

Natural Resources
Natural Resources,

$\mathrm{P}$ rosperity in California has always depended on the effective management of limited water supplies. Today that management is more critical than ever, as the state prepares for unprecedented population growth yet seeks to maintain agricultural productivity,

wildlife and aquatic habitats, and ecological integrity.

Early in the 1900s, during another period of rapid growth, Californians constructed dams to provide a greater, more reliable water supply. Managers gave little thought to the ecological consequences of their actions, altering flow regimes and destroying some ecosystems. They conducted widespread drainage of wetlands without fully considering the contributions of these aquatic and estuarine ecosystems to water and air purification and biodiversity.

Today, "there is a massive environmental debt to repay in California, which is reflected in the degraded nature of so many of our streams, lakes and estuaries," wrote UC Davis biologist Peter Moyle in the March-April 2000 California Agriculture. "We can fix things now, or we can wait until conditions get worse and we experience even more strongly the loss of benefits provided by healthy ecosystems."

"Fixing" aquatic ecosystems does not require the recreation of a pristine environment from the past, Moyle noted. It means re-establishing a balance in ecosystem structure and function to meet the needs of plants, animals and humans while maintaining a region's diverse and vibrant economy. In one recent example of such re-establishment, UC Agriculture and Natural Resources (ANR) scientists have spearheaded education and research programs to improve water quality across the grazed rangeland ecosystems of California.

California rangelands provide forage for cattle and calves, the state's 4th-largest agricultural commodity valued at $\$ 1.75$ billion in 2002. Rangelands occupy about 57 million of our 101 million acres statewide. Of these, 24 million (42\%), are privately owned and provide $90 \%$ of the state's cattle forage.

The major drainage basins of the state are largely comprised of rangeland. While rangelands only intercept about $15 \%$ of the precipitation in the state, almost all surface water in California passes through them. Approximately 9,000 miles of streams and 125,000 acres of wetlands associated with springs, wet meadows and vernal pools occur within California rangelands.

Poorly managed livestock grazing can affect California's water quality by reducing vegetation cover, potentially changing wetland/riparian species composition, and increasing temperature, sediment, nutrients and pathogens in waterways. Livestock can physically impact California waters through their hoof-action, compacting wetland areas and breaking down stream banks. Many scientists and regulators consider grazing a potential nonpoint source of pollution on rangelands. However, recent studies have also shown that proper grazing management can provide benefits; for example, well-managed grazing near vernal pools had the beneficial effect of promoting native vegetation.

In 1990, leaders in the livestock industry initiated an effort with the state's Range Management Advisory Committee (RMAC) and the State Water Resources Control Board (SWRCB) to develop a nonpoint source pollution control plan for nonfederal rangelands. At the same time, UC Cooperative Extension (UCCE) established the Rangeland Watershed Program with the USDA Natural Resources Conservation Service, addressing these issues through education, technical assistance and research. The California Rangeland Water Quality Management Plan (CRWQMP) was approved by RMAC and SWRCB in 1995.

This comprehensive plan directs rangeland owners and managers to voluntarily develop and implement ranch water-quality plans for their private land, helping them fulfill statutory requirements of the Clean Water Acts of 1977 and 1994, and the Porter-Cologne Act of 1969. By 1997, UCCE had developed and begun delivering the Ranch Water Quality Planning Shortcourse to enable landowners and managers to voluntarily comply with the plan (see page 134). Since 1997, more than 400 ranch water-quality plans have been developed covering 1.3 million acres of rangeland. UCCE is now expanding delivery of the course to farmers along the Central Coast.

The course is based upon the best scientific information available. During its implementation many questions were raised for which there were no research-based answers. These questions stimulated collaborations between campus-based faculty and UCCE specialists and advisors. One such collaboration showed that livestock-induced, nonpoint pollution can be reduced if sufficient vegetation is left in the uplands in riparian areas and along stream banks, and if livestock are not allowed to concentrate in riparian areas and along streams. Other projects demonstrated the value of residual dry matter in reducing sediment movement; the relationship of grazing management practices and water quality in springs; the origin and movement of pathogens from livestock and wildlife into waterways; and the effectiveness of vegetative buffer strips in filtering sediment, nutrients and pathogens. Several articles in this issue report on research aimed at preserving the state's critical aquatic resources (see pages 138 to 163).

If California is to ensure the availability of high-quality water, we must augment the kind of integrated research and extension efforts that fostered the successful ranch waterquality plans. Research must employ ecological, economic and social approaches, in addition to engineering, to solve water problems.

By examining the diverse biological, physical and socioeconomic components of the water-quality issue, we can provide reliable information to help managers make the decisions that will ensure California's future. 